\title{
EVALUATION OF THE STATE AND SHADE OF WHITE SPOT LESIONS AFTER TREATMENT WITH DIFFERENT REMINERALIZING AGENTS ( AN IN-VIVO COMPARATIVE STUDY )
}

\author{
Hany Helmy Elsayed Mohammed ${ }^{1}$, Mostafa Saber Mohamed Ata ${ }^{2}$ Walaa Mohamed Ahmed Elsamolly ${ }^{3}$
}

\begin{abstract}
Objective: This study was performed to evaluate the effect of three remineralizing agents' (Curodont repair, Clinpro XT varnish, and Clinpro white varnish) application on the state and shade of white spot. Materials and methods: Twenty patients were included in this study. The state and shade of white spot lesions before the application of the remineralizing agents were assessed using two devices, which are the Diagnodent Pen and Vita easyshade V. The affected nearest right tooth to the midline was treated with Curodont ${ }^{\mathrm{TM}}$ Repair, while the affected nearest left tooth to the midline was treated using Clinpro ${ }^{\mathrm{TM}}$ XT Varnish, and the third right or left affected tooth was treated using Clinpro white varnish (3M ESPE Dental). After the application, each white spot lesion of the treated tooth was evaluated immediately, after three months and after six months. Results: Both Curodont ${ }^{\mathrm{TM}}$ Repair and ClinproTM XT Varnish showed significant improvement in the state $(p<0.001)$ and shade $(p<0.001)$ of the lesions after application, both immediately and after three and six months, with no significant difference between the effect of both treatments ( $\mathrm{p}=0.140$ and $\mathrm{p}=0.985$ respectively). Clinpro white varnish showed no significant improvement in the state and shade after application, immediately or after three and six months. Conclusion: Curodont ${ }^{\mathrm{TM}}$ Repair and Clinpro ${ }^{\mathrm{TM}}$ XT Varnish showed significant improvement in the progression white spot lesions. Clinpro white varnish showed no significant effect.
\end{abstract}

KEYWORDS: White spots lesions, Remineralizing agents, Curodont, Clinpro XT

\section{INTRODUCTION}

White spot lesions are the earliest macroscopic evidence of enamel caries. White spots are evident when the amount of subsurface minerals lost (demineralization) exceeds the amount of minerals gained (remineralization) for a long period of time ${ }^{(1)}$

The fluoride varnish was a gold standard for the treatment of white spot lesion ${ }^{(2)}$. However, fluoride has a dose-response relationship, and the careless handling of fluoride toothpastes may lead to adverse effects such as fluorosis ${ }^{(3)}$. A range of new therapeutic agents including non-fluoridated products has been developed to enhance the enamel remineralization. A few examples of the widely used remineralization materials are casein phosphopeptide amorphous calcium phosphate (CPP-ACP) and bioactive glasses.

CPP-ACP is an amorphous calcium phosphate (ACP)-based bioactive material stabilized by casein phosphopeptide (CPP). The most recent approach for the remineralization is the biomimetic remineralizing agents, such as the self-assembling peptide P11-4.

1. Doctorate Candidate, Operative Dentistry, Faculty of Dentistry, Al-Azhar University, Cairo.

2. Professor of Operative Dentistry, Faculty of Dental Medicine, Al-Azhar University, Cairo.

3. Lecturer of Operative Dentistry Faculty of Dental Medicine, Al-Azhar University, Cairo.

-Corresponding author: dentohany83@gmail.com 
The self-assembling peptide P11-4 (Curodont repair) is designed to mimic enamel matrix proteins and forms a 3D matrix that contributes to the de novo hydroxiapatite formation, which has been used for remineralization of subsurface lesions. Besides subjecting the monomers to self-assembly into a fibrillar scaffold in the presence of environmental triggers, it has been reported that P11-4 has high affinity to calcium ions in saliva which also leads to the formation of enamel crystals around the enamel matrix ${ }^{(4)}$.

Clinpro XT (3M ESPE) is a highly filled resinmodified glass ionomer-based and light-curable fluoride varnish (LCFV). The varnish layer is claimed to remain intact for more than 5000 brushing strokes and can resist the toothbrush abrasion and normal wear for 6 months or longer. The effectiveness of Clinpro XT varnish has been investigated for dentinal hypersensitivity and remineralization, but its role in the reduction of enamel demineralization is not entirely clear ${ }^{(5)}$.

Clinpro white varnish contains 22,600 ppm fluoride and an innovative tri-calcium phosphate ingredient. The tri-calcium phosphate in Clinpro white varnish is milled with fumaric acid during manufacturing. This creates a protective layer around the calcium to keep it separate from the fluoride in the varnish. After Clinpro white varnish is applied to the tooth surface, the resin slowly dissolves and releases fluoride, calcium and phosphorus ions into the saliva. Fluoride and calcium react to form calcium fluoride which aids in sensitivity reduction ${ }^{(6)}$.

In our study, we investigated the effect of self-assembling peptide P11-4 (Curodont repair), resin modified glass ionomer varnish (Clinpro
XT varnish) and Tri-calcium phosphate varnish (Clinpro white varnish) on the state and shade of white spot lesions after different periods.

\section{SUBJECTS AND METHODS}

Twenty patients were included in the study. Each patient was informed about the nature of the study, eligibility criteria included patients less than 30 years old, systematically healthy and has fully erupted non-cavitated anterior teeth and the patients consented to periodic evaluation.

The affected teeth were divided according to the remineralizing agent used. The affected nearest right tooth to the midline treated using Curodont ${ }^{\mathrm{TM}}$ Repair (Mectron Deutschland Vertriebs $\mathrm{GmbH}$, Cologne, Germany). The affected nearest left tooth to the midline treated using Clinpro ${ }^{\mathrm{TM}}$ XT Varnish Durable Fluoride-Releasing Coating (3M ESPE Dental). The third right or left affected tooth treated using Clinpro white varnish (3M ESPE Dental). All remineralizing agents are shown in Fig. 1.

We assessed the state of white spot lesions before the application of the remineralizing agents using two devices:

1. Diagnopen 2190, which is a diagnostic tool that identifies and quantifies the initial demineralization. This can be referred to fluorescence assessment, which can be considered a suitable method. It depends on the detection of the emitted fluorescence after a modulated red light is applied because caries-induced changes in teeth lead to increased fluorescence at specific excitation wavelengths.

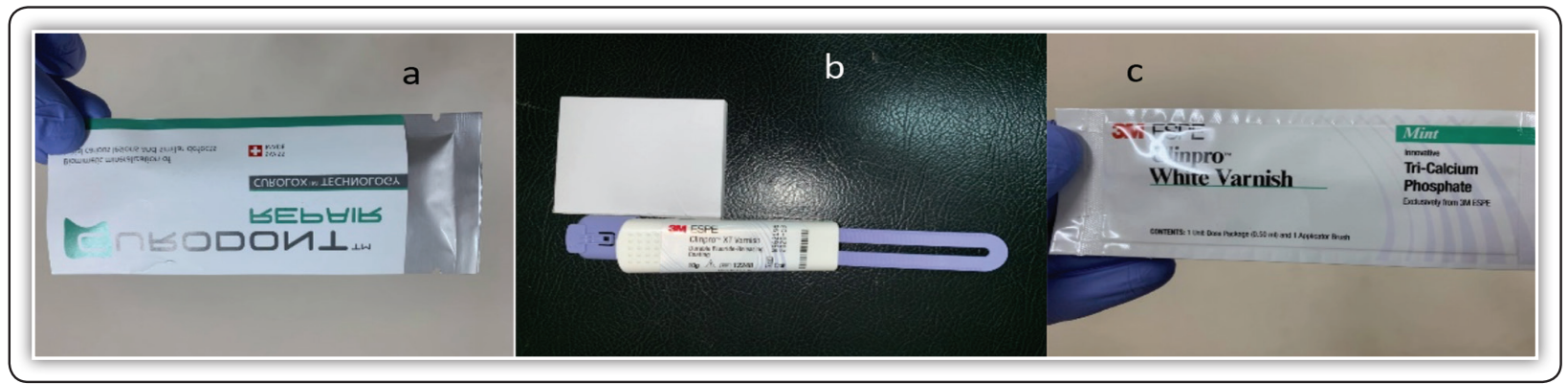

FIG (1) Materials used in the study. a. Curodont Repair. b. Clinpro XT Varnish. c. Clinpro White Varnish 
2. VITA Easyshade V (VITA Zahnfabrik, Bad Säckingen, Germany), which is the subject of this study, is a portable spectrophotometer and a new fifth generation of Easyshade. A spectrophotometer functions by measuring the spectral reflectance or transmittance curve of a specimen. It is useful in the measurement of surface color.

\section{Application of the remineralizing agents:}

Curodont Repair Application was performed as follows: Tooth polishing (with normal prophy paste), wiping with diluted sodium hypochlorite $2 \%$ (placed on a cotton swab) for 20 seconds, washing, etching with phospohoric acid $35 \%$ for 20 seconds, and then washing one more time was done prior curodont application.

First, the stick of Curodont repair solution is pushed in and then pulled out with its wetted sponge head, followed by gentle application of Curodont Repair for 5 minutes.

Clinpro XT varnish application was performed as follows: Enamel Etching with 37\% o-phosphoric acid gel for 15 seconds, washing and the drying for 15 seconds was done. The paste was extruded and the mixing was done using small spatula (paste/liquid) together rapidly for 15 seconds until a smooth consistency and a glossy appearance material was obtained. The application was made with a brush and it was placed as a thin layer on the tooth surface and light cured for 20 seconds, the coating was wiped with a moist cotton applicator.

Clinpro white varnish was performed as follows: areas to be treated was "toothbrush cleaned", no drying took place. It took a second to paint it on, no further steps are necessary after the application.

\section{Measuring the change of shade and state of lesions:}

After application of remineralizing agents, each white spot lesion of the treated teeth was evaluated immediately, after 3 months and after 6 months, using Vita Easyshade V and Diagnodent pen 2190 to evaluate the changes in shade and state of the lesions.

\section{RESULTS}

\section{A. Effect of the different remineralizing agents on the state of the lesions:}

Results showed that there were no significant differences between the mean scores of the state of the lesions before the application of all the remineralizing agents used in the study. Results also showed that there were no significant differences between the mean scores of the state of the lesions immediately after the application of all the remineralizing agents used in the study. After 3 months, results showed that there was no significant difference between the mean score of the state of the lesions treated with Curodont repair and the mean score of the state of the lesions treated with Clinpro XT varnish $\left(\mathrm{p}_{1}=0.444\right)$.

Also, the results showed that there was a significant difference between the mean score of the state of the lesions treated with Curodont repair and the mean score of the state of the lesions treated with Clinpro white varnish $\left(\mathrm{p}_{2}=0.001\right)$. In addition, there was a significant difference between the mean score of the state of the lesions treated with Clinpro XT varnish and the mean score of the state of the lesions treated with Clinpro white varnish $\left(\mathrm{p}_{3}=0.040\right)$.

After 6 months, results showed that there was no significant difference between the mean score of the state of the lesions treated with Curodont repair and the mean score of the state of the lesions treated with Clinpro XT varnish $\left(\mathrm{p}_{1}=0.140\right)$. Also, the results showed that there was a significant difference between mean score of the state of the lesions treated with Curodont repair and the mean score of the state of the lesions treated with Clinpro white varnish $\left(\mathrm{p}_{2}=0.002\right)$. In addition, there was no significant difference between the mean score of the state of the lesions treated with Clinpro XT varnish and the mean score of the state of the lesions treated with Clinpro white varnish $\left(\mathrm{p}_{3}=0.240\right)$. 
TABLE (1): Comparison between the effect of different remineralizing materials on the state of the lesions after different periods

\begin{tabular}{|c|c|c|c|c|c|}
\hline Diagnodent & $\begin{array}{c}\text { Curodont } \\
(\mathrm{n}=20)\end{array}$ & $\begin{array}{c}\text { Varnish XT } \\
(\mathrm{n}=\mathbf{2 0})\end{array}$ & $\begin{array}{c}\text { Clinpro white varnish } \\
(\mathrm{n}=\mathbf{2 0})\end{array}$ & $\mathbf{F}$ & $\mathbf{p}$ \\
\hline \multicolumn{6}{|l|}{ Before } \\
\hline Mean \pm SD & $22.55 \pm 3.94$ & $21.80 \pm 3.19$ & $20.90 \pm 3.37$ & & \\
\hline \multicolumn{6}{|l|}{ Immediately } \\
\hline Mean \pm SD. & $21.0 \pm 3.77$ & $20.40 \pm 3.14$ & $20.05 \pm 3.19$ & & \\
\hline \multicolumn{6}{|l|}{ After 3 months } \\
\hline Mean $\pm \mathrm{SD}$ & $16.50 \pm 4.20$ & $17.85 \pm 3.39$ & $20.60 \pm 2.70$ & $7.189 *$ & $0.002 *$ \\
\hline Sig. bet. grps. & \multicolumn{3}{|c|}{$\mathrm{p}_{1}=0.444, \mathrm{p}_{2}=0.001^{*}, \mathrm{p}_{3}=0.040^{*}$} & & \\
\hline \multicolumn{6}{|l|}{ After 6 months } \\
\hline Mean \pm SD. & $17.50 \pm 3.43$ & $19.45 \pm 3.22$ & $21.10 \pm 2.92$ & 6.364* & $0.003 *$ \\
\hline Sig. bet. grps. & \multicolumn{3}{|c|}{$\mathrm{p}_{1}=0.140, \mathrm{p}_{2}=0.002^{*}, \mathrm{p}_{3}=0.240$} & & \\
\hline
\end{tabular}

F: F for ANOVA test, Pairwise comparison bet. each 2 groups were done using Post Hoc Test (Turkey)

$\mathrm{p}$ : $\mathrm{p}$ value for comparing between the studied groups

$\mathrm{p}_{1}: \mathrm{p}$ value for comparing between Curodont and Varnish XT

$\mathrm{p}_{2}: \mathrm{p}$ value for comparing between Curodont and Clinpro white varnish

$\mathrm{p}_{3}: \mathrm{p}$ value for comparing between Varnish XT and Clinpro white varnish

*: Statistically significant at $\mathrm{p} \leq 0.05$

\section{B. Effect of different remineralizing agents on the shade of the lesions:}

TABLE (2): Comparison between the effect of different remineralizing materials on the shade of the lesions after different periods

\begin{tabular}{|c|c|c|c|c|c|}
\hline Easy shade & $\begin{array}{c}\text { Curodont } \\
(\mathrm{n}=20)\end{array}$ & $\begin{array}{c}\text { Varnish XT } \\
(\mathbf{n}=\mathbf{2 0})\end{array}$ & $\begin{array}{c}\text { Clinpro white varnish } \\
(\mathrm{n}=20)\end{array}$ & $\mathbf{F}$ & $\mathbf{p}$ \\
\hline \multicolumn{6}{|l|}{ Before } \\
\hline Mean \pm SD & $22.953 .02 \pm$ & $21.353 .33 \pm$ & $21.852 .89 \pm$ & & \\
\hline \multicolumn{6}{|l|}{ Immediately } \\
\hline Mean \pm SD. & $20.752 .83 \pm$ & $20.03 .18 \pm$ & $21.352 .98 \pm$ & & \\
\hline \multicolumn{6}{|l|}{ After 3 months } \\
\hline Mean \pm SD. & $18.353 .25 \pm$ & $18.253 .23 \pm$ & $21.052 .86 \pm$ & $5.199 *$ & $0.008^{*}$ \\
\hline \multirow{2}{*}{\multicolumn{6}{|c|}{$\frac{\text { Sig. bet. grps. }}{\text { After } 6 \text { months }}$}} \\
\hline & & & & & \\
\hline Mean \pm SD. & $19.202 .93 \pm$ & $19.353 .18 \pm$ & $21.602 .46 \pm$ & $4.379 *$ & 0.017 * \\
\hline Sig. bet. grps. & \multicolumn{3}{|c|}{$\mathrm{p}_{1}=0.985, \mathrm{p}_{2}=0.028^{*}, \mathrm{p}_{3}=0.042^{*}$} & & \\
\hline
\end{tabular}

F: F for ANOVA test, Pairwise comparison bet. each 2 groups was done using Post Hoc Test (Tukey)

$\mathrm{p}$ : $\mathrm{p}$ value for comparing between the studied groups

$\mathrm{p}_{1}: \mathrm{p}$ value for comparing between Curodont and Varnish XT

$\mathrm{p}_{2}: \mathrm{p}$ value for comparing between Curodont and Clinpro white varnish

$\mathrm{p}_{3}: \mathrm{p}$ value for comparing between Varnish XT and Clinpro white varnish

*: Statistically significant at $\mathrm{p} \leq 0.05$. 
Results showed that there were no significant differences between the mean scores of the shade of the lesions before the application of all the remineralizing agents used in the study. Results also showed that there were no significant differences between the mean scores of the shade of the lesions immediately after the application of all the remineralizing agents used in the study. After 3 months, results showed that there was no significant difference between the mean score of the shade of the lesions treated with Curodont repair and the mean score of the shade of the lesions treated with Clinpro XT varnish $\left(\mathrm{p}_{1}=0.994\right)$. Also, results showed that there was a significant difference between the mean score of the shade of the lesions treated with Curodont repair and the mean score of the shade of the lesions treated with Clinpro white varnish $\left(\mathrm{p}_{2}=0.022\right)$. In addition, there was a significant difference between the mean score of the shade of the lesions treated with Clinpro XT varnish and the mean score of the shade of the lesions treated with Clinpro white varnish $\left(\mathrm{p}_{3}=0.017\right)$. After 6 months, results showed that there was no significant difference between the mean score of the shade of the lesions treated with Curodont repair and the mean score of the shade of the lesions treated with Clinpro XT varnish $\left(\mathrm{p}_{1}=0.985\right)$. Also, results showed that there was a significant difference between the mean score of the shade of the lesions treated with Curodont repair and the mean score of the shade of the lesions treated with Clinpro white varnish $\left(\mathrm{p}_{2}=0.028\right)$. In addition, there was no significant difference between the mean score of the shade of the lesions treated with Clinpro XT varnish and the mean score of the shade of the lesions treated with Clinpro white varnish $\left(\mathrm{p}_{3}=0.042\right)$.

\section{DISCUSSION}

Cavitated carious lesions at the macroscopic level have been traditionally treated with surgical methods involving complete caries removal and sealing. There is a growing evidence and international consensus supporting the use of less invasive interventions focusing on white lesion control rather than the removal of the affected tissue $^{(7)}$.

Therefore, the use of restorative treatment is limited primarily to cavitated "non-cleansable" carious lesions, or to restore the function, form, and aesthetics of affected teeth. For "early" carious lesions, current evidence suggests the use of noninvasive and nonrestorative methods ${ }^{(8)}$, like sealing carious lesions (sealants and resin infiltration), and remineralization procedures mainly with fluorides varnishes, gels, and toothpaste or by using CPPACP (casein phosphopeptide amorphous calcium phosphate) vehicles alone or in combination with fluoride interventions ${ }^{(9)}$.

In our study, we chose to evaluate three different lines of treatment of white spot lesions with different mechanisms of action: self-assembling peptide P11-4 (Curodont repair), resin modified glass ionomer varnish (Clinpro XT varnish) and tricalcium phosphate varnish (Clinpro white varnish). The state and shade of white spot lesions were evaluated after 3 different periods of application of each material using DIAGNOdent pen and VITA Easyshade guide spectrophotometer.

Regarding Curodont repair, the results are in agreement with Ceci et al ${ }^{(10)}$, they explained that this may be due to the mechanism of action of P11-4, which is based on the formation of threedimensional scaffolds capable of promoting the deposition of hydroxyapatite. This process of assembling in scaffolds is initiated by specific environmental factors. P11- 4 passes from a state of isotropic liquid of low viscosity to a gel phase for $\mathrm{pH}$ values lower than 7.4 and in the presence of cations. The anionic groups of P11-4 scaffolds' lateral chains would attract calcium ions, causing the precipitation of hydroxyapatite de novo ${ }^{(11)}$.

On the other hand, these results are in disagreement with Wierichs et al ${ }^{(12)}$, who compared recommended and novel treatment methods regarding their ability to hamper the demineralization and as 
a consequence mask the artificial enamel caries lesions. For specimens treated with the self-assembling peptide, P11-4 a significantly higher mineral loss was observed compared with the respective negative control samples being brushed. They speculated that one of the reasons why the additional use of P11-4 seemed to even hamper the "demineralizing inhibiting effect" of the fluoride toothpaste could be the $\mathrm{pH}$-depending reactiveness of P11-4. At $\mathrm{pH}>7.2$, P11-4 is obtained as an isotropic fluid which is supposed to be transformed into a viscous birefringent nematic state in the $\mathrm{pH}$ range 5.0-7.0. In the nematic state, P11-4 seems to promote remineralization in vitro by presumably diffusing into the lesions and producing 3-dimensional gels comprising $\beta$-sheet aggregates ${ }^{(13)}$. Therefore, it might be speculated that an effect of the enhanced incorporation of $\mathrm{Ca}$ and $\mathrm{P}$ from saliva pronounce remineralization after the application of the self-assembling peptide, might be observed in the same setting but under net-remineralizing conditions.

Examination of various studies comparing the remineralization activities of fluoride containing agents and Curodont Repair (P11-4) suggests that P11-4 has a superior efficacy. An in vitro study that was carried out showed that Curodont repair had high mechanical properties even at a depth of $125 \mu \mathrm{m}$. The study emphasized that the mechanical properties of Curodont repair were superior to the fluoride-containing agent at a depth of $200 \mu \mathrm{m}^{(14)}$.

As regarding Clinpro XT varnish, these results are in agreement with Kumar ${ }^{(15)}$. They explained that these results may be due to the fact that Clinpro XT varnish is a resin-modified glass ionomer based on the methylacrylate modified polyalkenoic acid. The varnish provides the major benefits of glass ionomer materials including adhesion to the tooth surface and sustaining fluoride release. The fluoride resides in fluoroaluminosilicate glass particles, reacting at the surface provide the immediate release, while bulk provides a reservoir of fluoride for sustained release. It also contains calcium glycerophosphate which can provide calcium and phosphorous release over the life of the coating 3-6 months.

These results also are in agreement with Scotti et al ${ }^{(16)}$, they assessed that Clinpro XT showed better performance than fluoride. This fact could have occurred due to the chemical bond between glass ionomer of Clinpro XT Varnish and the tooth surface, which allows longer maintenance time. On the other hand, some studies claim that the addition of $\mathrm{Ca}$ and $\mathrm{P}$ ions to a glass ionomer-based material increases their availability for binding to the released $\mathrm{F}$ ions.

As regarding Clinpro white varnish, the results are in agreement with Godoi et al ${ }^{(17)}$. The latter evaluated soluble and insoluble fluoride concentrations in commercial varnishes: Enamelast (Ultradent Products), Duraphat (Colgate-Palmolive) and Clinpro white varnish (3M ESPE), and their remineralization effect on artificial caries enamel lesions, using surface and cross-sectional microhardness evaluations. Enamelast and Duraphat showed significantly higher enamel micro-hardness values than the control and the Clinpro groups. However, the evaluation of the treatments showed that the enamel surface micro-hardness values were higher with Enamelast and Duraphat varnishes than Clinpro group. This suggests that the former agents presented greater potential for enamel surface remineralization than the latter. However, the mean fluoride concentrations found in the varnishes evaluated in this study were lower than the values declared by the manufacturer, especially for Clinpro white varnish, in which a mean of $7336.27 \mathrm{ppm}$ soluble and insoluble fluoride concentration was verified.

These results are in disagreement with Said etal ${ }^{(18)}$. They compared remineralization potential of topical fluoride varnishes with added calcium phosphatebased delivery systems on artificial enamel caries. They concluded that Clinpro white varnish achieves significant remineralization of enamel carious lesions. Clinpro white varnish had similar enamel remineralization effect as Duraphat. They assessed 
that in Clinpro white varnish, fTCP is produced by functionalizing b-TCP with silica, which provides linking opportunities with hard tissue defects under acidic conditions. It penetrated throughout enamel without invading the inter prismatic organic material that could have promoted the greater uptake of calcium, phosphate, and fluoride in demineralized enamel ${ }^{(19)}$.

\section{CONCLUSION}

Our study concluded that Curodont ${ }^{\mathrm{TM}}$ Repair and Clinpro ${ }^{\mathrm{TM}}$ XT Varnish showed significant improvement in the progression white spot lesions, while Clinpro white varnish showed no significant effect on the white spot lesions.

\section{REFERENCES}

1. Silverstone LM. Structural alterations of human dental enamel during incipient carious lesion development. In: Rowe N, editor Proceedings of Symposium on Incipient Caries of Enamel, Nov 11-12 Ann Arbor, MI: University of Michigan School of Dentistry 1977. p. 3-42.

2. Mann AB, Dickinson ME. Nanomechanics, chemistry and structure at the enamel surface. Monogr Oral Sci 2006;19:105-31.

3. LagerweijMD, Ten Cate JM. Remineralization of enamel lesions with daily applications of a high-concentration fluoridegel and a fluoridated toothpaste: An in suit study. Caries Res 2002; 36: 270-274

4. Soares, R., De Ataide, I. D. N., Fernandes, M., \& Lambor, R. Assessment of enamel remineralisation after treatment with four different remineralising agents: A scanning electron microscopy (SEM) study. Journal of Clinical and Diagnostic Research: JCDR, 11(4), ZC136-ZC141.

5. Bhandary S, Hegde MN. A clinical comparison of in-office management of dentin hypersensitivity in a short term treatment period. Int J Biomed Adv Res 2012;3:169-74.

6. Wierichs RJ, Stausberg S, Lausch J, Meyer-Lueckel H, Esteves-Oliveira M. Caries-Preventive Effect of NaF, $\mathrm{NaF}$ plus TCP, NaF plus CPP-ACP, and SDF Varnishes on Sound Dentin and Artificial Dentin Caries in vitro. Caries Res. 2018;52(3):199-211.

7. Innes NP, Schwendicke F. Restorative thresholds for carious lesions: systematic review and meta-analysis. J Dent Res. 96, 2017; (5):501-508.
8. Schwendicke F, Frencken JE, Bjørndal L, Maltz M, Manton DJ , et al. 2016. Managing carious lesions: consensus recommendations on carious tissue removal. Adv Dent Res. 28, 2016; (2):58-67.

9. Gupta N, Mohan Marya C, Nagpal R, Singh Oberoi S, Dhingra $\mathrm{C}$. A review of casein phosphopeptide-amorphous calcium phosphate (CPP-ACP) and enamel remineralization. Compend Contin Educ Dent. 2016; 37(1):36-39.

10. El Mansy MM, Gheith M, El Yazeed AM, Farag DBE. Influence of Er, Cr: YSGG (2780 nm) and Nanosecond Nd: YAG Laser (1064 nm) Irradiation on Enamel Acid Resistance: Morphological and Elemental Analysis. Open Access Maced J Med Sci. 2019 ;30;7(11):1828-1833.

11. Kirkham J, Firth A, Vernals D. Self-assembling peptide scaffolds promote enamel remineralization. J Dent Res 2007; 86:426-430.

12. Wierichs RJ, Kogel J, Lausch J, Esteves-Oliveira M. Effects of self-assemplinpeptide P11-4, fluorides, and caries infiltration on artificial enamel caries lesions in vitro. Caries Res. 2017;51(5):451-459.

13. Aggeli A, Bell M, Carrick LM, Fishwick CW, Harding R, Mawer PJ. PH as a trigger of peptide $\beta$-sheet self-assembly and reversible switching between nematic and isotropic phases. J Am Chem Soc 2003; 125: 9619-9628.

14. Pianotti RS, Ambrozaitis JD and McNamara TF. Cariostatic activity of calcium glycerophosphate in hamsters: topical vs dietary administration. J DentRes 1976; 55: 1092-1096.

15. Kumar Jena A, Pal Singh S, Kumar Utreja A. Efficacy of resin modified glass ionomer cement varnish in the prevention of white spot lesions during comprehensive orthodontic treatment: a split-mouth study. J Orthod. 2015 Sep; 42(3):200-7.

16. Scotti CK, Velo MMAC, Brondino NCM, Guimarães $\mathrm{BM}$, Furuse AY. Effect of a resin-modified glass ionomer with calcium on enamel demineralization inhibition: an in vitro study.

17. Godoi FA, Carlos NR, Bridi EC, Amaral FLBD, França FMG. Remineralizing effect of commercial fluoride varnishes on artificial enamel lesions. Braz Oral Res. 2019 27;33: e044.

18. Mohd Said SN, Ekambaram M, Yiu CK. Effect of different fluoride varnishes on remineralization of artificial enamel carious lesions. Int J Paediatr Dent. 2017 May;27(3):163-173.

19. Elkassas D, Arafa A. Remineralizing efficacy of different calcium-phosphate and fluoride based delivery vehicles on artificial caries like enamel lesions. J Dent 2014; 42: 466-474. 